\title{
Evaluation of popularity of multi-lingual educational web games - do all children speak English?
}

\author{
Dasun Weerasinghe, Lisa Lazareck, Patty Kostkova, David Farrell \\ City eHealth Research Centre, \\ City University London \\ dasun. weerasinghedcity.ac.uk
}

\begin{abstract}
Playing computer games is widely popular among children and teenagers as an entertainment activity; however, computer games can also be easily transformed into tools for education. City University London's City eHealth Research Centre (CeRC) has developed such educational web games as a part of a European Project, e-Bug (www.e-bug.eu) to improve pupils understanding of the importance of hand and respiratory hygiene and responsible antibiotic use. This paper studies the usage of the Games between January 2009 and March 2010, specifically for 10 European Union countries. The Games were first provided in English-only and it was found that over half of the users were from non-UK countries. Once the Games were translated into multiple European languages, it was found that users preferred to play the Games in their native tongue. Thus, English was not a hindrance to Game playing/access; however, the option of using another language was always taken once provided. Users found the website through search engines and direct links from schools and other websites, and over 60,000 visitors played the Games at least once. The quantitative data used to investigate our research questions stemmed from the Games website server logs.
\end{abstract}

Keywords: educational web games, game evaluation, web logs, translation

\section{Introduction}

Nowadays, computer games for entertainment are commonly played by children and teenagers whilst, simultaneously, the educational gaming sector is growing - becoming a popular concept and teaching tool in the educational/academic sector. The European wide and DG SANCO funded "e-Bug" Project developed two web games to both entertain and educate pupils about microbes, hygiene and appropriate antibiotic use: the Junior Game (for 9-12 year olds), and the Senior Game (for 13-15 year olds). (The e-Bug Project also developed corresponding teaching packs as resources for teachers and classrooms.) The Junior Game incorporates a quiz (like 'Who Wants to be a Millionaire') and platform (like 'Super Mario Brothers') game, and the Senior Game was developed as a story-based detective game (like the 'Phoenix Wright Series'). Both games were developed using Flash software and then they were embedded into the e-Bug Website (www.e-bug.eu).

Both Games fall within the genre of 'role-playing games' or RPGs, such that they are both heavily narrative-driven [2], and therefore translations into the languages of the e-Bug partners were essential [2]. 
Specifically, the Games were translated into 10 European languages: Belgian-French, BelgianFlemish, Czech, Danish, French, Greek, Italian, Polish, Portuguese, and Spanish. Thus, in their completed form, the Games were unique, multi-language tools for teaching an agreed set of learning objectives.

Throughout 2009, a number of evaluation studies were performed with pupils from four primary schools around the UK [3, 4]; however, in this study, we investigate the multi-language versions of the games from the point of accessibility and usability. In particular, we addressed the following research questions:

1. Do non-English speaking (native) pupils play the e-Bug games in English, or is the language a barrier?

2. Does this differ in junior versus senior schools (where English is typically taught)?

3. Does the availability of games in multiple languages determine the choice to play in native language?

4. What is the overall geographic distribution of users (or game players) throughout the duration of the Project?

5. Did users only play either the Junior or Senior Game once ('unique' users), or were they 'returning' users who played either the Junior or Senior Game more than once.

6. How did the pupils find the games online; i.e., what are the main keyword searches used in popular search engines that users specified to locate the games? Which websites were used to find the games?

\section{Method}

Web server logs provide complete and accurate information about all browsing activity on a website. For example, web server logs can provide the following information: IP address or hostname of the hypertext transfer protocol (http) request that, using a DNS lookup, can determine the geographical location of the user; date and time of the http request; the page requested; the returned status of the page; the type of browser and screen size; the keywords entered to locate our games on the Internet; and the referring Universal Resource Locator (URL) - if available (i.e., the website that refers the user to another website). Web server logs are stored by each server that hosts the website. This paper describes the results of analysing the web server logs of the e-Bug website, specifically with respect to the web access of the Junior Game and Senior Game from the beginning of January 2009 (when the Junior Game was launched in English) to the end of the Project in March 2010 - and as the data relates to the aforementioned research questions. The data was processed using a proprietary log analysis tool called Sawmill [5]. Sawmill can produce a set of standardised reports that cover information - such as visits, hits, content viewed, user demographics and popular keywords and referrers - as well as perform bespoke queries.

\section{Results and Evaluation}

\subsection{Overall use of Junior and Senior Games}

The Junior Game went online in January 2009 and from its online inception to March 2010, it was played 14,638 times by 7,835 'unique' users. A unique user only plays either the Junior or Senior Game once; however, a user is also considered unique if they play the Junior Game and then later return to the website to play the Senior Game. Figure 1a shows the number of unique 
users who played the Junior Game during this time period. The two main peaks of activity occur in May 2009 and September 2009 corresponding to the global swine flu outbreak (when the traffic to the e-Bug website quadrupled [6]) and the e-Bug Project launch, respectively. The number of Junior Game players increases after January 2010, when the multi-language versions became available.

The Senior Game went online in English in July 2009 and from its online inception to March 2010 , it was played 9,285 times by 4,070 unique users. Figure $1 \mathrm{~b}$ shows the number of unique user who played the Senior Game during this time period. The two main peaks of activity occur in September 2009 and after January 2010 corresponding to the e-Bug Project launch and availability of the multi-language games, respectively.

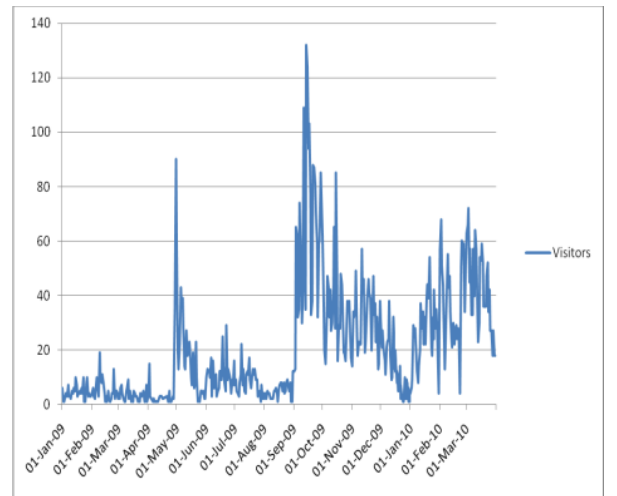

Figure 1a: Unique users - Junior Game

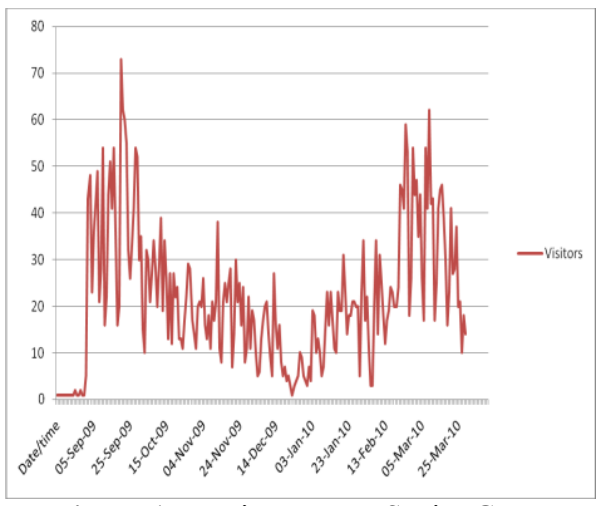

Figure 1b: Unique users -Senior Game

\subsection{Popularity comparison for English and multi-language Games amongst English and non-English users}

The evaluation of the geographical distribution of users is three-fold, whereby the countries of interest include the 11 partner countries (repeated here for convenience): Belgium (both French and Flemish speaking combined), Czech Republic, Denmark, France, Greece, Italy, Poland, Portugal, Spain, and United Kingdom. First, the overall geographic distribution of users is examined during the entire duration by which the Game was 'live' (which varies per Game). Second, the geographic distribution of users playing only the English-version of the Games is assessed. Third, the geographic distribution of users playing the Games in their own language is inspected. A comparison is made between the latter two assessments.

\subsubsection{Overall distribution of users (January 2009 - March2010)}

The Junior Game data runs from January 2009 to March 2010; whereas the Senior Game data runs from July 2009 to March 2010. Figure 2 illustrates the percentage of users from each of the partner countries who accessed the Games during these time periods. For both Games, the majority of users are from the UK whereby $55 \%$ and $44 \%$ of the total users played the Junior and Senior Game respectively. Portugal follows, such that $13 \%$ and $27 \%$ of the total users played the Junior and Senior Game respectively. France found the Junior Game more appealing, such that $13 \%$ played it but only $4 \%$ played the Senior Game. Conversely, Greece 
found the Junior Game less appealing, such that with 3\% played it and $8 \%$ played the Senior Game. Overall, the Junior Game was less played in comparison to the Senior Game in the nonUK countries.

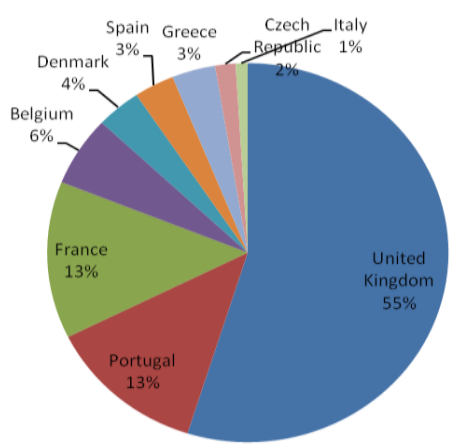

Figure 2a: Overall - Junior Game

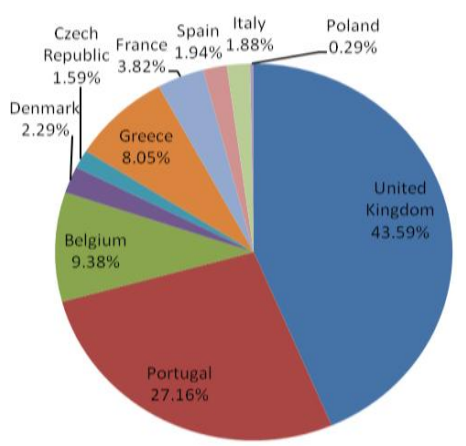

Figure 2b: Overall - Senior Game

\subsubsection{Stage 1: Games in English}

The Junior Game was available in English-only from January 2009 to January 2010; whereas the Senior Game was available in English-only from July 2009 to January 2010. Figure 3 illustrates the percentage of users from each of the partner countries who accessed the Games during these time periods. The English-only user distribution is quite similar to that discussed for the overall distribution in Section 3.2.1. For the Junior Game, the English version was most popular in the UK (64\% of total users), and then Portugal (12\%), and France (10\%). For the Senior Game, the UK users played the most ( $42 \%$ of total users) followed by Portugal $(33 \%)$, Belgium (11\%) and Greece (10\%). Interestingly, 36\% and 58\% of the total users (Junior Game and Senior Game) during this time period were non-English speakers. A higher percentage of non-English pupils played the Senior Game; however, this is not surprising as the target demographic (13-15 year olds) most likely had English studies as part of their school curriculum.

Table 1 illustrates the total number of users during this English-only period, including the breakdown of users from other countries. The Project partners have been highlighted, whereas there are a number of other countries accounted for, such as Australia, Canada, Chile, Ireland, Italy, Malta.

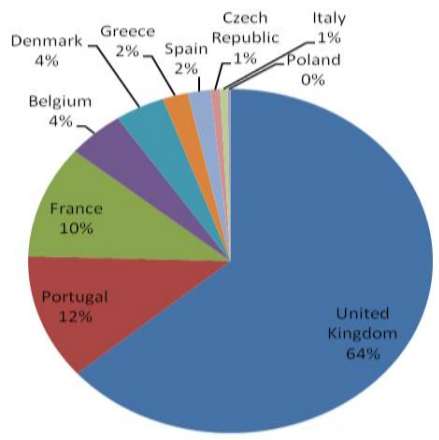

Figure 3a: English - Junior Game

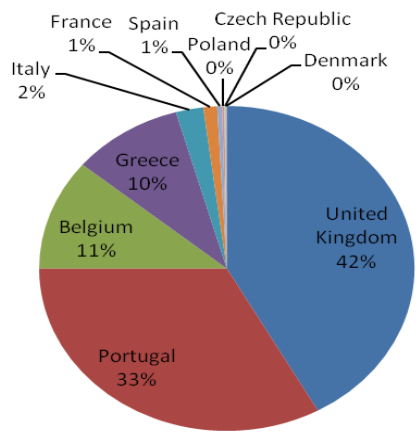

Figure 3b: English - Senior Game 


\begin{tabular}{|l|r|r|l|r|r|}
\hline \multicolumn{2}{|c|}{ Junior Game } & \multicolumn{3}{c|}{ Senior Game } \\
\hline Geographic Location & Returning Users & Unique Users & $\begin{array}{l}\text { Geographic } \\
\text { Location }\end{array}$ & Returning Users & Unique Users \\
\hline UK & 4,271 & 2,370 & UK & 1,246 & 814 \\
\hline Portugal & 830 & 600 & Portugal & 248 & 742 \\
\hline France & 740 & 660 & Belgium & 210 & 214 \\
\hline Belgium & 318 & 244 & Greece & 76 & 186 \\
\hline Denmark & 281 & 163 & USA & 52 & 61 \\
\hline USA & 151 & 135 & Italy & 33 & 46 \\
\hline Greece & 140 & 115 & Australia & 31 & 19 \\
\hline Spain & 127 & 93 & France & 23 & 23 \\
\hline Australia & 97 & 49 & New & 17 & 15 \\
\hline Chile & 57 & 36 & Netherlands & 16 & 12 \\
\hline Czech Republic & 53 & 47 & Malta & 16 & 16 \\
\hline Germany & 46 & 31 & Brazil & 13 & 13 \\
\hline Netherlands & 44 & 20 & Iran & 12 & 11 \\
\hline Italy & 41 & 32 & Ireland & 12 & 9 \\
\hline Malta & 39 & 30 & Germany & 12 & 12 \\
\hline Canada & 36 & 27 & Hong Kong & 10 & 9 \\
\hline Sweden & 28 & 19 & India & 9 & 9 \\
\hline Ireland & 24 & 21 & Cambodia & 9 & 8 \\
\hline India & 20 & 18 & Spain & 2 \\
\hline
\end{tabular}

Table 1: English Junior Game and Senior Game Users: Country Tally

\subsubsection{Stage 2: Games in Multiple Languages}

Both the Junior and Senior Games ran in multiple languages from January 2010 to March 2010. Figure 4 illustrates the percentage of users from each of the partner countries who accessed the Games in their native language during these time periods. (It is assumed that the majority of users playing the Games on a non-UK website are indeed from that non-UK country - see the following Section for further details.) Interestingly, and for the Junior Game, the percentage of users who played the games in their own language (Figure 4) was similar to the percentage of users who played the games in English (Figure 3). For example, $15 \%$ and $8 \%$ of the total users played the Junior Game in Portuguese and French - in comparison to the $12 \%$ and $10 \%$ of the total users that played the same Game in English. Thus, given the choice of languages, each user prefers to play in their native tongue - which is reasonable since the games contain a great deal of dialogue. However, the patterns of the Senior Game are not as congruent. For example, less users played the Senior Game in Portuguese (11\%) in comparison to English (33\%) - but more Danish users played the Senior Game in Danish (7\%) rather than English (0\%). An increase in user participation (from $0-1 \%$ using the English-only version) is found for Poland (1\%), Czech Republic (5\%), Spain (5\%), France (10\%) - see Figure 4. Overall, it is encouraging that users from the partner countries played their Games in their native language, when this option (i.e., the translation) was provided.

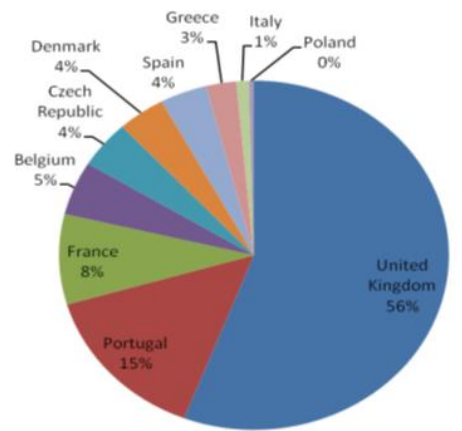

Figure 4a: Multi-Language - Junior Game

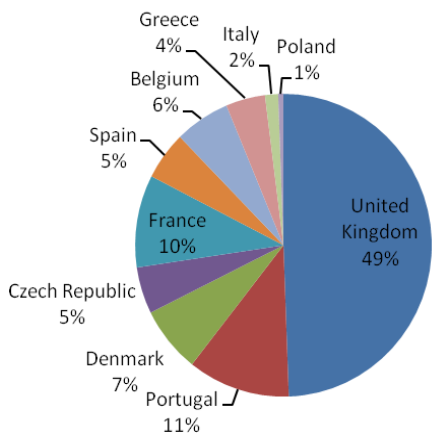

Figure 4b: Multi-Language - Senior Game 


\subsection{A comparison of games played by European children in English and their languages}

Table 2 illustrates the tally of unique visitors who played the Games during this time period, and from which website. (The tally of returning visitors has been left out for the sake of space.) For example, it was found that on the English e-Bug website, 1,073 users came from the UK and played the Junior Game; whereas 21 users came from Australia, 27 from the USA, 4 from Oman, 9 from Pakistan, etc. Note how not one user from any of the 10 partner countries played the games in English, even though previously, almost half of the Game users were from nonUK countries. The introduction of multi-language games, as located via the language selection section on the e-Bug website, resulted in the games being played in the native tongue of the user. For example, the majority of users (249) of the Portuguese Junior Game were indeed from Portugal, with 14 hailing from Brazil, 2 from Sweden, 2 from the UK, 2 from Japan and 1 from the USA. The users from Belgium would have played the Games in either French or Flemish and this too is noted in the Table. In all cases, the majority of Game users on each partner section of the e-Bug website, were native to that country.

\subsection{How were the Games found online?}

For promoting the Games, it is important to ascertain how children search for and inevitably find specific game topics and the e-Bug Games themselves. Many Internet search engines were used to find the e-Bug website - such as Google, Yahoo, Bing, etc. A sample of keyword searches that brought users to the e-Bug Games included: food hygiene games, bug games, microorganisms games, disease detective games, hygiene games for children, bug detective games, bug games for children, food and hygiene games. Using Google and Yahoo search engines, we tested each of these keywords to find out which are most effective in finding our eBug Games. The keywords "microorganisms games" and "bug games for children" were the most effective and our website was listed in their Top 10 results. Meanwhile, a search for "food hygiene games" listed the e-Bug website on the 2nd page of Google and the 3rd page of Yahoo. We have noticed that some of the keywords are not popular in main search engines; however, they may be more effective in local, i.e., country-specific search engines:

http://www.netmasters.co.uk/european search engines/

We have identified that some schools were effective in referring their pupils to the e-Bug Games website from their own school website, such as: Edward Francis Junior School in Essex, Arbours Primary School in Northampton, Churchill School in Kent, and Firside Junior School in Norfolk. Meanwhile, some educational websites also referred their visitors to the e-Bug Games pages, such as: BSB Virtual Learning Environment, and www.school-portal.co.uk. In addition to schools that collaborated with the Project during development, other institutions learned about the initiative through partners' and government promotional campaigns.

\subsection{Do users play the Game(s) once or over-again?}

The Games teach a set of learning objectives as agreed upon by the e-Bug Project partners. The explicit evaluations demonstrated that children had improved their knowledge through the game playing experience; however, are the games enjoyable enough to attract the pupils' attention again? Using the web server logs, we were able to track the percentage of users who played either the Junior or Senior Game once ('unique') or on several occasions ('returning') as previously defined above. Note that links to the Junior and Senior Games were displayed in the main page on the e-Bug website, and in January 2010, these Game links and launch buttons were made more visible and given more prominence throughout the website - especially with 
the launch of the multi-language versions. Therefore, we analysed the number of users between 01 January 2009 and 01 January 2010 followed by the 01 January 2010 to 31 March 2010 timeline.

For the Junior Game, $20 \%$ of users played the Junior Game once, but $15 \%$ returned and played it again. These values increased to $30 \%$ when the multi-language versions were uploaded onto the website. For the Senior Game, $10 \%$ of users played the Junior Game once, and $8 \%$ returned and played it again. These values also increased to $15 \%$ (unique) and $26 \%$ (returning) after January 2010 . Therefore, it is concluded that the addition of multi-language games increased Game user-activity.

\begin{tabular}{|c|c|c|c|c|c|c|c|c|c|c|c|c|c|c|c|c|c|c|c|c|c|}
\hline \multicolumn{22}{|c|}{ Junior Game (Unique Users) } \\
\hline \multicolumn{2}{|c|}{ UK } & \multicolumn{2}{|c|}{ Portugal } & \multicolumn{2}{|c|}{ France } & \multicolumn{2}{|c|}{ Spain } & \multicolumn{2}{|c|}{ Czech Republic } & \multicolumn{2}{|c|}{ Denmark } & \multicolumn{2}{|c|}{ Greece } & \multicolumn{2}{|c|}{ Italy } & \multicolumn{2}{|c|}{ Belgium-French } & \multicolumn{2}{|c|}{ Belgium-Flemish } & \multicolumn{2}{|c|}{ Poland } \\
\hline $\mathrm{UK}$ & 1,073 & \begin{tabular}{|l|l} 
Portugal \\
\end{tabular} & 249 & France & 198 & \begin{tabular}{|l|} 
Spain \\
\end{tabular} & 113 & Czech & 61 & Denmark & 73 & Greece & 90 & \begin{tabular}{|l|l|} 
Italy \\
\end{tabular} & 27 & France & 36 & Belgium & 84 & Poland & 14 \\
\hline USA & 27 & Brazil & 14 & Belgium & 13 & \begin{tabular}{|l|l|} 
Mexico \\
\end{tabular} & 7 & UK & 4 & Faroe Island: & 4 & Cyprus & 2 & UK & 1 & Belgium & 29 & Netherland & 2 & UK & 7 \\
\hline Australia & 21 & Japan & 2 & Tunisia & 4 & \begin{tabular}{|l|} 
Argentina \\
\end{tabular} & 5 & & & Germany & 2 & UK & 2 & \begin{tabular}{|l|l} 
Japan \\
\end{tabular} & 1 & $\begin{array}{l}\text { Canada } \\
\end{array}$ & 3 & Poland & 2 & Lithuania & 1 \\
\hline $\begin{array}{l}\text { Pakistan } \\
\end{array}$ & 9 & $\mathrm{UK}$ & 2 & Canada & 3 & \begin{tabular}{|l} 
Colombia \\
\end{tabular} & 5 & & & Norway & 2 & & & Malta & 1 & Reunion & 1 & $\mathrm{UK}$ & 1 & & \\
\hline Germany & 7 & USA & 2 & Cambodia & 2 & Chile & 4 & & & Sweden & & & & & & & & USA & & & \\
\hline Lithuania & 7 & Sweden & 2 & & & & & & & & & & & & & & & & & & \\
\hline Malaysia & 7 & & & & & & & & & & & & & & & & & & & & \\
\hline Malta & 7 & & & & & & & & & & & & & & & & & & & & \\
\hline UAE & 7 & & & & & & & & & & & & & & & & & & & & \\
\hline Oman & 4 & & & & & & & & & & & & & & & & & & & & \\
\hline \multicolumn{22}{|c|}{ Senior Game (Unique Users) } \\
\hline \multicolumn{2}{|c|}{$\mathrm{UK}$} & \multicolumn{2}{|c|}{ Portugal } & \multicolumn{2}{|c|}{ France } & \multicolumn{2}{|c|}{ Spain } & \multicolumn{2}{|c|}{ Czech Republic } & \multicolumn{2}{|c|}{ Denmark } & \multicolumn{2}{|c|}{ Greece } & \multicolumn{2}{|c|}{ Italy } & \multicolumn{2}{|c|}{ Belgium-French } & \multicolumn{2}{|c|}{ Belgium-Flemish } & \multicolumn{2}{|c|}{ Poland } \\
\hline $\mathrm{UK}$ & 503 & $\begin{array}{l}\text { Portugal } \\
\end{array}$ & 117 & France & 86 & Spain & 51 & Czech & 50 & Denmark & 74 & Cyprus & 43 & \begin{tabular}{|l|} 
Italy \\
\end{tabular} & 27 & $\begin{array}{l}\text { France } \\
\text { Prence }\end{array}$ & 15 & Belgium & 40 & \begin{tabular}{|l|} 
Poland \\
\end{tabular} & 6 \\
\hline USA & 38 & Brazil & 6 & $\begin{array}{l}\text { Belgium } \\
\end{array}$ & 7 & \begin{tabular}{|l|l} 
Argentina \\
\end{tabular} & 3 & UK & 1 & Sweden & 1 & France & 2 & \begin{tabular}{|l|} 
Japan \\
\end{tabular} & 1 & Belgium & 13 & Netherland & 2 & \begin{tabular}{|l|} 
UK \\
\end{tabular} & 1 \\
\hline Australia & 19 & UK & 2 & USA & 3 & \begin{tabular}{|l|l|} 
Venezuela \\
\end{tabular} & 2 & $\begin{array}{l}\text { Pakistan } \\
\end{array}$ & 1 & & & USA & 1 & \begin{tabular}{|l|} 
Malta \\
\end{tabular} & 1 & Algeria & 2 & UK & 2 & & \\
\hline Pakistan & 13 & Spain & 1 & Cambodia & 2 & Chile & 2 & & & & & & & UK & 1 & Tunisia & 1 & & & & \\
\hline Sweden & 6 & & & Morocco & 2 & \begin{tabular}{|l|} 
USA \\
\end{tabular} & 2 & & & & & & & & & & & & & & \\
\hline Malaysia & 5 & & & & & & & & & & & & & & & & & & & & \\
\hline Canada & 4 & & & & & & & & & & & & & & & & & & & & \\
\hline Lithuania & 4 & & & & & & & & & & & & & & & & & & & & \\
\hline $\begin{array}{l}\text { NewZealand } \\
\end{array}$ & 3 & & & & & & & & & & & & & & & & & & & & \\
\hline
\end{tabular}

Table 2: Multiple language Junior Game and Senior Game Users: Country Tally 


\begin{tabular}{|c|c|c|}
\hline \multicolumn{3}{|c|}{ Junior Game } \\
\hline Between 01 January 2009-01 January 2010 & \multicolumn{2}{|c|}{ USERS } \\
\hline & Unique & Returning \\
\hline Number of users to the home page & 25,037 & 48,772 \\
\hline Number of users played the Junior Game & 5,051 & 7,754 \\
\hline Percentage (\%) of users who played the Junior Game & $20 \%$ & $15 \%$ \\
\hline Between 01 January 2010 - 31 March 2010 & \multicolumn{2}{|c|}{ USERS } \\
\hline & Unique & Returning \\
\hline Number of users to the home page & 8,631 & 20,094 \\
\hline Number of users played the Junior Game & 2,494 & 5,662 \\
\hline Percentage (\%) of users who played the Junior Game & $30 \%$ & $30 \%$ \\
\hline \multicolumn{3}{|c|}{ Senior Game } \\
\hline Between 01 July 2009-01 January 2010 & \multicolumn{2}{|c|}{ USERS } \\
\hline & Unique & Returning \\
\hline Number of users to the home page & 20,415 & 39,493 \\
\hline Number of users played the Senior Game & 2,411 & 3,298 \\
\hline Percentage $(\%)$ of users who played the Senior Game & $10 \%$ & $8 \%$ \\
\hline Between 01 January 2010 - 31 March 2010 & \multicolumn{2}{|c|}{ USERS } \\
\hline & Unique & Returning \\
\hline Number of users to the home page & 8,631 & 20,094 \\
\hline Numer of users played the Senior Game & 1,259 & 5,254 \\
\hline Percentage $(\%)$ of users who played the Senior Game & $15 \%$ & $26 \%$ \\
\hline
\end{tabular}

Table 3: Junior and Senior Games: Unique and Returning Users Tally

\section{Conclusion}

Analysis of the e-Bug web server logs between January 2009 and March 2010 first revealed that providing the e-Bug Games in English-only did not hinder users from playing/accessing the Games; however, when users were given the opportunity to play the same Games in their native language, they did so for the Junior and Senior Games. In fact, no one user from the Partner collaborating countries played the Games in English once translations were provided. Around half of all users reside outside of the UK, and through various promotions and search engines, the Games have even reached outside of e-Bug partner countries. Over 60,000 visitors played the Games at least once, and over 130,000 visitors returned to play again. Future research includes the development of Game scoring techniques, and further Game promotion.

\section{References}

[1] D. Farrell, P. Kostkova, L. Lazareck, D. Weerasinghe. "Developing web games to teach microbiology," J. of Antimicrobial Chemotherapy, in-press, Summer 2010.

[2] M. O'Hagan. "Video games as a new domain for translation research," Revista Tradumàtica Traducció I Tecnologìes de la Informaciǒ I la Comunicaciǒ 05: Localitzaciǒ de videojocs: http://www.fti.uab.cal/tradumatica/revista : ISSN 1578-7559.

[3] D. Farrell, P. Kostkova, J. Weinberg, L. Lazareck, D. Weerasinghe, C.A.M. McNulty. "Can computer games wash your hands? An evaluation of the e-Bug junior game," J. of Antimicrobial Chemotherapy, inpress, Summer 2010.

[4] L.J. Lazareck, D. Farrell, P. Kostkova, D. Lecky, C. McNulty, "Learning by gaming - evaluation of an online game for children," Proc. 32nd IEEE EMBS Conference, (Buenos Aires, Argentina; Aug. 31-Sept. $4,2010)$ in-press.

[5] Universal $\log$ file analysis and reporting proprietary software: Sawmill. Accessed June 2010. Available: http://www.sawmill.net.

[6] E. de Quincey, P. Kostkova, G. Jawaheer, D. Farrell, C. McNulty, J. Weinberg. "Evaluating the online activity of users of the e-Bug website: evaluation of e-Bug," J. Antimicrobial Chemotherapy, in-press, Summer 2010 